Peer-Reviewed Article

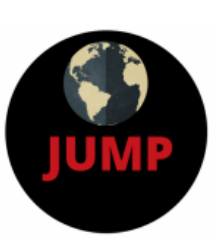

$\underline{\text { OJJED }}$

ISSN: 2574-3465 Print/ ISSN: 2574-3481 Online

Volume 5, Issue SI (2021), pp. 47-66

(C) Journal of Underrepresented and Minority Progress http://ojed.org/jump

\title{
We are no one's shrinking violets: Black women educators demand more in the time of COVID-19
}

Francheska D. Starks

University of West Georgia, USA

S. Mia Obiwo

University of Memphis, USA

Adrian Dunmeyer

Douglass County Schools, USA

Arkeria Wright

Clayton County Schools, USA

Christal Walker

Georgia State University, USA

\begin{abstract}
The purpose of this article is to center the perspectives and experiences of five Black women educators during the COVID-19 pandemic. We use a lens of Black Feminist Thought, which is based in the everyday experiences of Black women, to present our narratives. Our study uses personal vignettes and cross-case analysis to identify key issues emanating from COVID-19particularly those pertaining to our social locations as Black women educators across the spectrum of public education (e.g., elementary, high school, comprehensive university, research university). This study provides a supportive environment for voicing stories and developing useful strategies for coping with issues related to our social locations, including shifts in education and society.
\end{abstract}

Keywords: Black Feminism, Black Feminist Thought, Black women educators, counter-story, COVID-19 


\section{INTRODUCTION}

"A Flower... a flower is relatively small compared to the rest of the universe. Everyone has many associations with the flower...Still in a way, nobody sees a flower really. We haven't taken time to look and to notice. To see takes

\section{time." - Ava DuVernay}

The United States of America has a profound history of sacrificing the safety and needs of some for the benefit of select others. It is apparent, perhaps now more than ever, how this sacrifice has materialized into the marginalization of minoritized groups and made it socially acceptable to ignore some of their most basic human needs, specifically Black women's needs. It is important to note that as authors, we identify as Black women and use the pronouns "our", "we" and "us" throughout this article to acknowledge our positionality and social locations when referring broadly to Black women and Black women educators more specifically. Our decision to include ourselves, through our language, in this article follows in the tradition of Black feminism (Collins, 1991; Evans-Winters, 2019; Walker 1983) and is an intentional act to produce qualitative research that recognizes and validates the individual and collective experiences of Black women.

In the same way that renowned writer, director, producer, and distributor Ava DuVernay speaks of "the flower" in the opening quote, the experiences of Black women in the United States of America have been overlooked by social policies that neither focus on, nor attend to the issues of our concern. For example, a lack of access to quality healthcare and the disproportionate impact of maternal morbidity and mortality rates (Howell et al., 2018) for Black women has been examined in relation to healthcare workers' implicit biases (Noursi et al., 2020). Also, the tragic ending of Breonna Taylor's life, a Black woman who police ambushed and murdered in her own home (North \& Cineas, 2020) is a recent and concrete example of the disrespect and disregard that has cost us our lives. In the wake of global pandemics, one caused by COVID-19, Black women faced a reality that our social positioning was further compromised and complicated in ways that many of us are still processing. However impacted Black women were (and are) by the effects of COVID-19 and the myriad of social injustices that we regularly experience, as authors we continue to be present in our families, in our careers, and in our lives. It is from this place that we enter into conversation-as five Black women who also serve in the world as professional educators. In this article, we speak for ourselves. We explore our personal challenges and triumphs, and work to center our unique perspectives amid a national and global crisis. Through the sharing of our individual stories, we seek not to represent Black women as a monolithic group, rather 
to recognize the nuances of our experiences while also identifying commonalities among our different perspectives that may serve to inform our future actions. In this article, we explore our personal and professional perspectives on the COVID-19 pandemic with the goals to 1) center the experiences of five Black women educators; 2) illuminate, from our perspectives, the unique challenges of supporting students who are members of historically marginalized and minoritized communities; and 3) give voice to our own stories as a way of coping with our individual and collective circumstances. As a collective of five Black women educators, it is our hope to shed light on our unique positionality in ways that others may come to understand our joys and struggles.

Black women educators have a long history of caring for our students and our communities through service and empowerment (Muhammad et al., 2020). History indicates that Black women educators have been attuned to social and political struggle and have actively participated through our content expertise and pedagogy in uplifting Black people and advancing agendas of freedom and social justice (Beauoeuf-Lafontant, 2002; Dixson, 2003; Ladson-Billings, 2009; Perkins, 1983; Smith, 2019). Some examples include historical African American women's literary societies that functioned as intellectual spaces where Black women cultivated social and political activism (Muhammad, 2012). Similarly, Mary McLeod Bethune and Septima Clark demonstrated Black women educators' commitments to utilizing education as a pathway to liberation by advocating for voting rights and other social issues (Bethune, 2001; Brown-Nagin, 1999; Hanson, 2003).

Historically, Black women educators' voices have been silenced and omitted from narratives on schools and schooling; yet, Black women, regardless of circumstance, have remained ever-present, working and thriving in schools (McClusky, 2014). Currently, research and scholarship focused on educators often omits or erases the experiences of Black women leaving this area of scholarship void of our perspectives (Dixson \& Dingus, 2008). We often remain more marginalized, particularly at the intersections of race, gender, and social class than Black men and White women (Crenshaw, 1989). During the time of COVID-19 when social stratifications have widened and people of color are disproportionately and negatively affected, Black women bear the brunt of negative outcomes at the hands of a healthcare system that is already least responsive to our needs (Wilson, et al., 2020). Ultimately, we seek to know: What are our unique experiences as five Black women educators during the COVID-19 pandemic? We follow in the footsteps of countless women before us who have refused to be silenced, such as Maya Angelou, Angela Davis, Rosa Parks, Daisy Bates, Shirley Chisholm, and 
many contemporary Black women. In making our stories known we hope to inspire other Black women to do the same.

\section{WHO WE ARE}

We are five individuals who identify as Black/African American and woman. Additionally, we currently work as professional educators. We have varied educational backgrounds, job experiences, and other social locations (ex; social class, religion, sexuality, etc.) yet there is much that we share in common. We each have experience teaching in K-12 public school systems, have advanced degrees in the field of education, and have experience teaching in the Southeastern region of the United States. Adrian is a recent graduate of a Doctor of Education program in the area of curriculum and instruction and she is currently working as a high school English teacher in a public school. Chrissy is currently pursuing a Doctor of Philosophy degree in Early Childhood and Elementary Education while simultaneously working as an elementary educator. Arkeria earned her Doctor of Education degree in elementary education with a focus on curriculum and instruction and is currently working as an elementary educator. Mia and Francheska are both recent graduates who have earned their Doctor of Philosophy degrees in early childhood and elementary education. Mia currently works as an assistant professor and Francheska as an instructor, both at post-secondary institutions. It is important to share that we are not strangers to one another. Chrissy, Mia, Adrian, and Francheska attended the same institution for their graduate work, and Arkeria and Francheska have previously worked together as public school teachers. Throughout our various relationships as sister scholars, we have often discussed the challenges related to the COVID-19 pandemic and our positionalities as Black women educators. Our ongoing conversations prompted the blueprint of this work. Thus, our familiarity with one another, either directly or through another co-author, supported our collaborative efforts and willingness to be vulnerable in our writing.

\section{THEORETICAL PERSPECTIVES Overview of Black Feminist Thought}

To center our experiences as Black women educators working during the COVID-19 pandemic, we needed to ground our work in a theory that seeks to find truth and power in Black women's stories, knowledge, and work. Therefore, we ground this work in Black Feminist Thought (BFT) (Collins, 2000), which is a critical sociocultural theory that recognizes Black women as authorities on our own experiences, and aims to produce ideas about the social world through the self-definition and agency of Black women. As BFT places Black women at the center of analysis, it uses a critical approach to 
render Black women's experiences, methods of empowerment, and resilience valuable - regardless of the marginalized intersections of their identities and the dominant silencing of their voices (McClusky, 2014). In this study, we rely heavily upon a distinguishing element of BFT which is its equal concern for the oppression, resistance, agency, and self-defining mindsets and actions of Black women (Alinia, 2015). Black women's actions of resistance often directly oppose societal boundaries that are imposed upon us, and BFT allows us to center our own knowledge and wisdom by considering our responsesthe contours of our ways of living and being in the world.

Black feminist thought mandates social analyses that recognize power as interconnected and multifaceted (Dotson, 2015; Pérez, et al., 2017). There are five distinguishing features of BFT, which include a focus on both the oppression and activism of Black women, the significance of social change toward equity, Black women's collective experiences that create a group conscious and collective memory, the defiance of a monolithic conception of Black womanhood, and a matrix of domination constructed on social conceptions of race, gender, sexuality, class, and sexuality (Alinia, 2015; Collins, 2000). While we operationalize each distinguishing feature of BFT in this paper through providing and synthesizing examples from our own lives, we focus our analysis on the matrix of domination and discuss it in more detail in the next section.

\section{Matrix of Domination}

The matrix of domination as outlined in the theory of BFT centers around social locations of race, gender, class, sexuality, and nationality (Collins, 1991). The matrix itself is useful for considering the complexities of how power is organized as well as it operates. As an example, we are able to recognize the duality of roles as the oppressed, activist and oppressor that some Black women encounter through their lived experiences (Hancock, 2016). According to BFT (Collins, 2000), power is multi-faceted and can be conceptualized through several domains: structural, disciplinary, interpersonal and hegemonic. The domains of power are not mutually exclusive and organizing rules, policies and ideologies may simultaneously be part of multiple domains. We used the domains of power to inform how we thought about our experiences during the onset and the height of the COVID-19 pandemic. They guide our exploration as we share our individual and collective narratives about our government, our employers, our families, and our most inner thoughts and feelings during this time. We consider the following domains of power in our work: 
1. The structural domain guides us to consider how we may experience subordination through the regulation of citizenship and rights in institutionalized spaces.

2. The disciplinary domain urges us to explore how we manage oppression and power relationships that are aimed to silence our voices and render them less valuable.

3. The interpersonal domain connects us to the routine and everyday interactions that we experience with others.

4. The hegemonic domain represents the systemic ideologies and practices that reinforce and normalize White supremacy and the othering of minoritized groups (Alinia, 2015).

As we consider each of these power domains, BFT creates a space for our stories and experiences to expose how domination is organized and operates in both personal and institutionalized spaces such as schools. Furthermore, recounts of our experiences during COVID-19 become sites of resistance as we counter dominant narratives that may not accurately reflect our experiences as Black women and educators. In this article, we join together to collectively share how we are situated among the domains of power. We also shed light on the work that we do for ourselves and for our students.

\section{RESEARCH METHODOLOGY}

This study utilizes ethnography research methods, for we follow the assumption that research is not distinguishable from the Self (Lincoln \& Guba, 1985). Who we are and what we can be - what we can study and how we write about that which we can study - are always tied to our knowledge systems (Richardson \& St. Pierre, 2005). In this work, we prioritize our common knowledge system of Black womanhood to write ethnographic narratives that showcase our vulnerabilities, emotions, thoughts, relationships, and interpretative decision making as we reflect on the impact of COVID-19 and our roles in the field of education. We view narratives as verbal action. As we tell our stories from diverse perspectives, we seek to explain, inform, complain, confirm, and challenge the status quo. We emphasize our voices in ways that draw attention to what we communicate and how we communicate it as well as to our individual positions and social locations from which we speak (Chase, 2005).

Specifically, we use counter-storytelling to describe our realities as Black women educators in an effort to help readers bridge the gap between their worlds and ours (Delgado \& Stefancic, 2017). Counter-storytelling is described as "a method of telling the stories of those people whose experiences are not often told" (Solórzano \& Yosso, 2002, p. 32). Further, 
counter-storytelling can facilitate the building of community among racially minoritized groups by showing that we are not alone and that we can learn from the lived experiences of others (DeCuir-Gunby \& Walker-DeVose 2013). We employ our personal narratives as first-person counter-stories representing the experiences of five Black women educators positioned at different places along the education continuum spanning in social locations from elementary school to higher education. Thus, the results are presented in five vignettes in which each Black woman educator's counter-story is told from a unique perspective. Ava DuVernay reminds us "To see takes time" and in this spirit, rather than summaries, we have included each author's full vignette.

We took our study a step further by conducting a cross-case analysis of our vignettes to facilitate the comparison of commonalities and differences amongst our viewpoints. During first cycle coding, the first and second authors independently read and re-read the vignettes to develop inductive, initial codes using the elemental methods of descriptive and In Vivo coding (Saldaña, 2015). Descriptive coding summarizes in a word or short phrase the topic of a section within the vignettes. Whereas, In Vivo coding can be thought of as "literal coding" or codes that refer to the actual language found in the vignettes. The authors then compared and discussed the codes and built consensus on what constituted a code (e.g. vulnerability). This coding agreement was then applied to the vignettes. At the next level of analysis, the meaning units identified during first cycle coding were layered with deductive, a priori codes developed using the language of the domains of power represented in Black Feminist Thought. For example, all meaning units within the vignettes coded as vulnerability were reexamined for explicit and implicit connections to each of the domains of power. During the final stage of analysis, the vignettes were revisited to ensure that all salient meaning units were captured and coded. Each researcher maintained analytic memos to promote researcher reflexivity throughout the coding process (Miles, Huberman, \& Saldaña, 2014). The analytic memos encouraged conversations about our roles as researchers and the research relationship. We consistently discussed our own assumptions and how these preconceptions affect research decisions. Importantly, this work allowed us to achieve cultural intuition (Delgado Bernal, 1998) as we nurtured our personal and professional experiences, uplifted the theoretical literature of Black women, and engaged in an analytic process in which we stood in a central position of the research and analysis. 


\section{OUR STORIES \\ Adrian: A Strong Pillar in Trying Times}

Two years ago, while working on my dissertation, I asked my research participants the following question: What does it mean to be a Black woman teacher? While I don't remember every detail of their responses, I do recall the warmth they projected as they shared their thoughts, the pride they felt to voice their purpose, and the joy they exuded as they acknowledged their roles. I remember that they expressed power in being Black women teachers who become symbols of possibilities and dreams realized for Black and Brown students. I mention this here because I, too, am a Black woman teacher. I have since completed my research, but the power in my participants' words still resonates with me today.

The intersections of my identities have always contributed to how I navigate schooling, and the roles that I play in schools where I teach. This year, however, my identity was pushed front and center as I watched race and identity take center stage in discussions across our nation. In March of 2020, the world shut down due to COVID-19. Where I once left my home each day to educate young minds, by March, I was required to stay home for safety. As a country, we were instructed to socially distance ourselves and we paused our everyday lives for the sake of our health. But, as I began to teach and work from home, an alarm sounded across the Black community. As the world paused to combat COVID-19, the screams, yells, and piercing silence of Black bodies reverberated around the world due to brutal violence at the hands of law enforcement, and Black death. So, as the world stood still for "safekeeping," another virus was centered in our neighborhoods and on our news stations-racism in America.

As a Black woman teacher, watching protests during COVID-19 became painful reminders of our realities as Black folx in America, our positioning in society, and denial of our rights to humanity. As I watched crowds gather to demand justice and fight for Black humanity, my heart wept with frustration. And, I swelled with concern for the safety of myself, my family, and the Black bodies in our schools. As I sit and reflect on the responses of my participants of what our existence as Black women in schools means, I am reminded of their passion, and their commitment to humanizing students. And, today, as I write this piece I add to their sentiments by saying that our job is also to protect and harness Black joy.

As a teacher, on a "normal" day, I would usually go into my classroom, harness creativity, and encourage my students to see the potential in who they are and can be. But now, while teaching through the lens of my computer screen, I think critically about my purpose and presence in 
education. I think about how to teach my students about navigating schooling when we have a heightened awareness of our Black skin. Now, more than ever, I feel the weight of my purpose and presence-especially for my students who are Black and Brown, and are watching the symbolism of their skin determine their rights to breathe, sleep, and exist peacefully. I am informed by the intersections of my identities and my dark skin which place me in an inimitable space, where I not only experience the world through a unique lens, but am in a position, as a teacher, to educate and empower minds from that perspective. As a Black woman, teaching during COVID-19, my gender, my Black skin, and my knowledge makes me essential in the advancement of our society and in reminding my students of the power and joy of their beings - regardless of how systems in America personify their skin.

\section{Chrissy: A Seat at the Table}

"If they don't give you a seat at the table, bring a folding chair." - Shirley Chisholm

Although we [Black women in America] live in a country tainted by structural and institutional racism, we have a right to be here and to have our say in the direction of this nation. As a Black woman in America and a teacher of Black children, I am tired of teaching my students how to carry the weight of it all. I am tired of teaching them how to process a pandemic and being Black in America. While structural and institutional racism is nothing new, I am tired of teaching my kids how to be resourceful when their more privileged, often White, peers have all of the resources at their fingertips. My students have seen their lives ripped apart because of COVID-19. When our governor pushed for the city to open, I witnessed families struggle to meet their basic needs.

We continually hear a narrative that virtual learning creates equitable opportunities for all children. However, those opportunities should not be considered equitable when, nationwide, students have lost housing and are further experiencing food insecurity while those in more affluent areas are receiving brand new computers and one-on-one in-class intervention in addition to private tutoring at home. How are these experiences considered equitable when some students are forced to go to work with their parents to ensure they will have Wi-fi and free food while others simply have to wake up and head to their "work from home space" in a second or guest bedroom?

Inequities such as poverty and access to healthcare have led to reported increases in student absences, decreases in assignment completion, and an overall set up for failure. I am tired. I am tired of reading NewsELA 
articles and picture books like Something Happened in Our Town, to help my students process yet another murder of a Black man or woman. I am tired of logging into a Zoom meeting seeing the exhaustion on my students' faces because they were up all night due to the fear of their favorite items being taken, like their lives Pre-COVID. I am tired of forcing my students to take another state mandated test when they have not received nearly enough resources and instruction to feel successful. I understand we are all doing our best to survive in this current predicament, but some of our policy makers and superintendents just HAVE to do better.

\section{Arkeria: A Mother's Plea}

I don't know how many times I've heard "Find the strength God gave you!", in my lifetime. These "words of encouragement" have become a painful reminder of the lack of value Black women hold in America's society, inside and out of our communities. Hear me out. I have traumas surrounding many of my successes. Many of the things that warranted the statement above essentially affirmed or denied my greatness or the lack thereof. From grade school, through molestation, undergraduate, near death, rape, childbirth, master's degree, earning my doctorate, 2nd childbirth, loss of employment, starting businesses, homelessness, loss of my mother, COVID-19, and with many blessings in between, people expected greatness from me. They were not used to me, nor would they accept me, in any other form but that which represented strength. Yet, one day I broke! Depression set in, and this Black woman, this Black mother, this Black business owner, this Black educator had nowhere to go to recover. So, I kept going.... with the strength God gave me.

Historically, the concept of motherhood has been of central importance in the philosophies of people of African descent. It has been central to my life as well, but not without a cost. Being an African American single mother to a 17-year-old daughter and an 11-year-old son, I have not lived one day of parenthood without sacrifice. As mothers, we are sacrificing our lives each day to protect and provide by any means necessary for our Black children. We are haunted with the daily reports of killings of our Black and brown girls and boys. We are faced with healthcare biases when in need of medical treatment in our hospitals. We are terrified by the lack of care public education systems continue to demonstrate within their policies and laws. And during COVID-19, there has been no consideration for the Black mother that has to choose between the well-being of herself and her children or her job. 
What was proposed to teachers in my circumstance was that if asked to return to school for face-to-face instruction during the pandemic, we would be allowed to bring our children to work with us if we were unable to send them to school. So, as mothers, in order for me to keep my job, I would have had to not only expose myself to the dangers of contracting COVID-19 but also expose my children for the sake of "educating" as well.

As a homeschool parent for many years before returning to the classroom, I know that education can happen in the confines of your home with willingly invested parents and the proper online access. My local school district received millions of dollars to upgrade its technology platforms and provide adequate access for all students within the district. Distance learning programs across the globe have proven that this way of life and learning can work. To give teachers no other option in America but to die by the hands of lawmakers and stakeholders is disgusting to say the least. Both my son and I suffer from underlying health issues, so not to be considered in these school board decisions breaks my heart. We are afraid, as mothers, that we are not able to protect our children. We are afraid, as educators, that we will not be able to uplift and inspire our students. As Black people, we are traumatized by the constant fight for our right to humanity.

As Black women and mothers, we give it our all, yet we are overwhelmed with the demands to somehow dismiss our personal lives in order to graciously consider each and every child's personal life "for the sake of education". Why are we asked to "mother" students with care but not allowed to "mother" our own? Why are we then crucified for not being there $100 \%$ for our own children when the demand of our jobs and the pressures to be all and do all are placed on our shoulders? We are not allowed the space to breathe, to heal, to be Black freely! We are not given the grace, the support, the financial stability. No matter what, we are supposed to fight through societal traumas and workplace expectations without complaint or hesitation. Black women, Black mothers, and Black educators would like to see themselves as valuable in American society, the Mothers of Civilization-not disrespected, but protected.

\section{Mia: A Degree of Tenderness}

May your streets be paved with gold

Hope my whole hood make it home

'Cause the world can be toxic

'Specially when your skin look like chocolate

At one point they sold us for profit

But we made it out of the gauntlet, we chosen

- Tobe Nwigwe, Make it Home 
The Dean of the College of Education at my current institution is what I would call a proud and critically conscious Black woman. I mention this because, optimistically, I see her as a mirror of my own future. During our first college-wide faculty meeting at the beginning of the Fall 2020 semester, the Dean mentioned that we are amid three pandemics - the COVID-19 health pandemic; the racial injustice and systemic oppression pandemic as police brutality continues to roil Black and Brown people; and the economic pandemic resulting from the tight restrictions on movement to halt the spread of the virus. As I reflect on this rife triad and its effects on my life and my students' lives, I am reminded of how golden and resilient Black people are.

My "homeboy in my head" and fellow Igbo descendant, Tobechukwu Nwigwe whose lyrics I reference above, is a transcendent rapper and artist I credit significantly for helping me cope and stay optimistic while encouraging others - especially my Black folks - during these trying times. More than ever before, I have taken on the job of motivator, empathizer, and counselor in my role as a Black woman teacher educator. I instructed school-based courses with a culturally diverse group of preservice teachers preparing to teach in urban schools during the Spring and Summer 2020 semesters when remote learning was mandated. Many of the preservice teachers in my courses were not from the city and lived alone. Others had children, and some were not accustomed to virtual learning. Coupling the effects of the health pandemic with the racial injustice, protests, and riots taking place in our own city, I felt it was vital to address the current state of our society while cautiously considering the best ways to approach and navigate the unique perspectives of my students and their emotional tolls. Was I teaching a social foundations course on educational equity? No. I was actually teaching courses on early literacy instruction. However, it was essential that I gave my preservice teachers the degree of tenderness we all needed. We were all stripped of our traditional ways of being and as a responsive practitioner I could not ignore that. Course planning became arduous as there was so much to consider. The pressure of being known as a Black, critical educator also began to mount, for I did not have all of the answers to address our current reality. Through teaching with tenderness, I was able to model an embodied way of being that allowed us to admit what we knew and did not know; to listen thoughtfully to one another; to consider perspectives that we might have thought of as outside of our worldviews; to make room for emotions; to shed light on experiences that we have left unspoken; to form alliances; and to "see justice as key to our survival" (Thompson, 2017, p. 1).

A few of my Black students reached out to me for support. I gave them my time, without thinking twice about it, and continuously expressed to 
them, "Y'all, we are golden." It was therapeutic for me to watch them stay the journey and thrive throughout the spring and summer semesters when the entire teacher preparation program was full of uncertainty. Thus, our Zoom check-ins were mutually beneficial and served as a safe space for us all. We still meet virtually occasionally. As our busy schedules intensify, our checkins can be thought of as an analogy to the common question of care, "Did you make it home?"

I am now an assistant professor at a new institution and in a new city since graduating from my Ph.D. program in May 2020. As I continue to grow in my role as a Black woman teacher educator, I will uphold what I learned this year. That is, teaching is ever-changing. Teaching is taxing, so I must seek ways to deal. Teaching requires tenderness. And most importantly, as one who seldom has representation in higher education, teaching teachers should be an authentic yet therapeutic experience in which I share myself with students willingly, for it may benefit them in ways I have not imagined.

\section{Francheska: My Sister, Myself}

I struggled to write this vignette because it was difficult for me to simplify what was and still is a very surreal and unsettling experience. I began drafting this document, first through a free-write that included a combination of my thoughts, feelings, and emotions related to events that have transpired over the past 6 months:

Girl, let's talk writing a dissertation during a pandemic. The anxiety, the regret and panic have never been more real. There were several times when I thought that I should just throw in the towel. Better that than being run into the ground by systems. Music got me through. It still does today.

I realized that few things matter more than family and that my health is a gift, a blessing and should never be taken for granted.

I cried. A family friend died. I consoled family members. Tried to be there for others then realized I needed to be there for myself.

I gave myself permission to record my stream of consciousness as I engaged in what I realized was my first attempt to process my experiences through writing. As I continued to write, somewhat with the goal of narrowing my focus for this vignette, I kept revisiting the question - What does it mean to live in this body? What does it mean, right now, to live in $m y$ body? 
I have a Black body, one like my mother and my great-grandmother. And I am also more than my body. To my family, I am a daughter, sister, and friend. To my colleagues, I am an instructor and a recent graduate with my $\mathrm{Ph} . \mathrm{D}$. in education. It is in this context, as a doctoral student, that I find recent evidence of my embodied experiences and the coping mechanisms that I find useful for discussion in this article.

What does it mean, right now, to live in my body? I pondered this question in light of my role as a doctoral student working through drafts of my dissertation. Living in my body meant that I did not have time. There was no time to be afraid of COVID-19 or too concerned with the fact that it has further exacerbated inequities in social systems that have existed for over a century. There was no time to prioritize my mental and physical well-being given the abrupt halt of most social interaction and physical activity. There was no time to process the images of violence against Black bodies, Black women's bodies, that were plastered across news channels, newspapers, social media and the like. There was no time to grieve and I felt guilty for my innate desire to seek relief. After all, who was I to seek escape when the families of Atatiana Jefferson, Sandra Bland, George Floyd, Philando Castille, Ahmaud Arbery, and countless others did not have that choice.

I felt incredibly conflicted. All at once my dissertation research, which focused on Black women educators' experiences in life and in educational spaces, seemed both inconsequential and of the utmost importance. How could I focus on writing a stupid document at a time like this, and also how could I not share the important stories of the Black women who worked alongside me as participants? After I resolved to finish my dissertation and my program as planned, I simultaneously admitted to myself that I was not okay.

I was saddened, angry, and frustrated. My interpersonal relationships with White colleagues and acquaintances were strained. I was afraid, and also felt like I needed to be strong for my family. I believe that acknowledging my feelings allowed me to open myself up to different ways of coping during this time.

GirlTrek, a movement started by Black women, is one source from which I drew inspiration, joy, and relief as I created my own path toward healing. Specifically, their focus on joy as an act of resistance stood out to me during this time. Morgan Dixon and Vanessa Garrison, co-founders of the GirlTrek movement, advocate for walking as a path to wellness and healing for Black women. They recorded "Walk and Talks" in a podcast format, and I listened to these recordings as I began to walk for 30 minutes a few days per week. 
As a result of my walks my mood improved, I felt physically lighter and more agile. I enjoyed communing with nature (sunlight was key), and I even talked about the content of the "walk and talks" with friends who were also listening. I credit this movement as one of the reasons that I was able to begin to heal myself and find new ways to build community during this difficult time.

I have learned that I need community, particularly the community of other Black women. Vanessa and Morgan spoke so candidly about their experiences particularly during COVID-19 and also beyond. They talked about their ancestors, our ancestors, and the strengths that we carry as a part of our heritage, but more importantly to me they spoke about the need to reclaim joy, to make space for rest and to know that struggle is not my inheritance but that I can choose to relax and be grateful even in these uncertain times. Today, I know that I am enough and that my pain and my joy matter. I am grateful - currently for the opportunity to share my story through writing in this article.

\section{ANALYSIS AND DISCUSSION}

Our counter-stories, represented here as five vignettes, reveal themes central to Black women's identities as educators at various social locations across the field of education. As we analyzed the nuances of our unique perspectives, Black Feminist Thought and the four interrelated domains of power provided an important reminder that our experiences and identities are inevitably influenced by the organization of power relations in our society (Collins, 2000). We begin our discussion of the analysis at the interpersonal domain of power, which exposes our current reality through our vignettes, including our personal and professional routines and relationships. Inherent in all of our stories is the idea of vulnerability. Whether explicitly stated or implicitly observed, each of us expressed various emotions and experiences, and exposed layers of ourselves as an act of solidarity. The theme of ultimatums and sacrifice also revealed itself as a part of our interactions with others and adjustments to Self. In our roles as Black women and Black women educators, we have grown more accustomed to an increased degree of selflessness by choosing to give up our time and resources in an effort to ensure the well-being of our families, our students, and their loved ones. Collins' (1991) refers to this idea as othermothering which "consists of a series of constantly renegotiated relationships that African American women experience with one another, with black children, with the larger African American community, and with self" (p. 176). Each of the vignettes express the theme of othermothering as we all willingly accepted the responsibility of 
caring for Black children, teachers, and communities with hopes of prosperity in humanity. As a result of our altruistic ways, fatigue and exhaustion were often indicated as we worked overtime-mentally, physically, and emotionally - to meet the demands produced by the uncertainty within our classrooms and society. We responded to our fatigue with a deliberate attentiveness to our recovery; however, the level of action towards our recovery varied. Some of us acknowledged that healing was needed yet struggled to find time to prioritize the matter. Others of us sought out methods of recuperation from our exhaustion, which led to the theme of mindful coping. Resistance in the form of joy, liberation, and self-preservation; musical therapy; and spaces designated for Black people to gather safely are all mindful coping methods identified throughout our stories. We also commonly experienced a heightened awareness and responsiveness to our positionalities as Black people, women, educators, and researchers. There are countless moments throughout the vignettes in which we are honest with ourselves and others in ways that allowed us to begin seeking solutions. Likewise, the idea of heightened awareness and responsiveness also pertains to our relationships with students and their families. Threaded throughout the vignettes are examples of our moment-to-moment decisions based on our communities' and society's rapid changes and staggering events. We strategically planned our pedagogical moves as we acquired new information and observed our students keenly. In different ways, we each emphasized the unique worth of the Black woman educator. Our stories indicated how valuable we are to those around us. At the same time, many of us recalled experiences that initiated recognition of how valuable we are to ourselves. As we wrap up the explanation of how our vignettes showcase the interpersonal domain of power, it is important to mention that recognition of our value occurs along a spectrum-varying from those who value us to rules and systems that neglect us.

The disciplinary domain of power manages the oppression and organizational practices of the social institutions - the schools and communities - that we serve (Collins, 2000). Our stories specify the depth of oppression experienced by Black women educators, as we yearned for the same recognition that we received from our families and our students on an institutional level.

Even though our professional positions bestowed multiple responsibilities and high expectations upon us, we all consistently described a lack of recognition of our value within the workforce. Our vignettes expressed that Black women educators are more than teachers. Society expects us to function as counselors, sources of empowerment, and critical 
thinkers with no permission to be anything but strong. Subconsciously, we often sacrifice our wellness to uphold the unspoken rules and societal assumptions of what we should be. We communicated our awareness of the role of governance and discussed ways that we might find ourselves relegated in our professional lives for critically considering and acting on the systemic inequities present in our society. From the perspective of the structural domain of power that explores how Black women regulate within the subordination of their social locations, we found that regulation occurs through varying emotions. Many of us responded to our emotions by attempting to transform our social locations - altering the curriculum, choosing joy and optimism, or demanding that those in power enact change. The hegemonic domain of power upholds the ideologies and practices in schools and society that reinforce the often negative assumptions of Black women educators to justify oppression (Alinia, 2015). Collectively, our stories defy negative stereotypes imposed on Black women. These stories are about us. They represent a raw look at our lives in the midst of COVID-19, ongoing social injustice, and an economic plummet. Despite our circumstances, our stories represent our actions to choose self-definition over societal assumptions. We decided to unpack hegemonic ideologies and construct new knowledge about what it means to be a Black woman educator.

\section{CONCLUSION}

We are charged, by the foundations of Black Feminist Thought, with the call to examine both oppressions and activism as part of the experiences of Black women. The vignettes in this paper reveal elements of activism through the participants' narratives of attentiveness to our recovery, mindful coping, heightened awareness of our responsiveness, and recognition of our value. Through our vignettes we demonstrate that Black women are not simply acted upon in the world but we are active participants in creating the world we wish to see.

The vulnerability of participants who shared our experiences through vignettes allows for the visibility of the collective consciousness that Collins (2000) identifies as one of five defining features of Black Feminist Thought. The vignettes also provide evidence that although we, Black women, have a collective consciousness through our shared experiences of fatigue and exhaustion and ultimatums and sacrifice, we are not a monolith and exist in the world at various intersections although we share in common our race and gender.

When presenting the stories and experiences of Black women, it is essential to attend to the dualities of the social injustices that we 
endure while also recognizing the significance of our contributions of resistance, agency, self-definition and activism. It is equally as important to recognize the complexities of the presentations and dynamics of power within U.S. society. Black Femnist Thought, as a critical social theory, provides the framework for an examination that honors the duality and complexities of Black women's experiences and U.S. power structures, and grounds the authors' endeavor to represent our own stories.

In this article, we consider not only our individual experiences during the COVID-19 pandemic, but also a collective narrative of Black women's joys, triumphs and struggles. The counter-stories in this article provide insight into our individuality, our collective consciousness, and our resilience. We have taken the time, as Ms. DuVernay suggests, "to look and to notice" how these experiences have impacted us and our communities. During this pandemic we refuse to shrink or shy away from our responsibilities to our families, our education, our professions, and most importantly ourselves. Yet, we also demand, as evidenced by the theme of recognition of our value, to be seen and we refuse to remain invisible - in the margins. We matter. And as we find ways to cope and sustain our livelihood as Black women and as educators, we require more. Period.

\section{REFERENCES}

Alinia, M. (2015). On Black Feminist Thought: thinking oppressions and resistance through intersectional paradigm. Ethnic and Racial Studies, 38(13), 2334-2340.

Beauboeuf-Lafontant, T. (2002). A womanist experience of caring: Understanding the pedagogy of exemplary Black women teachers. The Urban Review, 34(1), 71-86.

Bethune, M. M. (2001). Mary McLeod Bethune: Building a better world: essays and selected documents. Indiana University Press.

Brown-Nagin, T. (1999). The transformation of a social movement into law? The SCLC and NAACP's campaigns for civil rights reconsidered in light of the educational activism of Septima Clark. Women's History Review, 8(1), 81-137.

Chase, S. E. (2005). Narrative inquiry: Multiple lenses, approaches, voices. In N. K. Denzin \& Y. S. Lincoln (Eds.), The Sage handbook of qualitative research (3rd ed., pp. 651-679). Sage.

Collins, P. H. (2000). Black feminist thought: Knowledge, consciousness, and the politics of empowerment. Routledge.

Collins, P. H. (1991). On our own terms: Self-defined standpoints and curriculum transformation. Nwsa Journal, 3(3), 367-381

DeCuir-Gunby, J. T., \& Walker-DeVose, D. C. (2013). Expanding the counter-story: The potential for critical race mixed methods studies in education. In M. Lynn, \& A. D. Dixson (Eds.), Handbook of critical race theory in education (pp. 248-259). Routledge.

Delgado Bernal, D. (1998). Using a Chicana feminist epistemology in educational research. Harvard Educational Review, 68, 555-582. 
Delgado, R., Stefancic, J., \& Harris, A. (2017). Critical Race Theory: An Introduction (3rd ed.). NYU Press,

Dixson, A. D. (2003). " Let's Do This!" Black Women Teachers' Politics and Pedagogy. Urban Education, 38(2), 217-235.

Dixson, A., \& Dingus, J. E. (2008). In Search of Our Mothers' Gardens: Black Women Teachers and Professional Socialization. Teachers College Record, 110(4), 805837.

Dotson, K. (2015). Inheriting Patricia Hill Collins's black feminist epistemology. Ethnic and Racial studies, 38(13), 2322-2328.

Evans-Winters, V. E. (2019). Black feminism in qualitative inquiry: A mosaic for writing our daughter's body. Routledge.

Hancock, A. M. (2016). Intersectionality: An intellectual history. Oxford University Press.

Hanson, J. A. (2003). Mary McLeod Bethune and Black women's political activism (Vol. 1). University of Missouri Press.

Howell, E. A. (2018). Reducing disparities in severe maternal morbidity and mortality. Clinical Obstetrics and Gynecology, 61(2), 387.

Ladson-Billings, G. (2009). The dreamkeepers: Successful teachers of African American children. John Wiley \& Sons.

Lincoln, Y., \& Guba, E. G. (1985). Naturalistic inquiry. Sage.

Miles, M. B., Huberman, A. M., \& Saldana, J. (2014). Qualitative data analysis: A methods sourcebook. Sage.

Muhammad, G. E. (2012). The literacy development and practices within African American literary societies. Black History Bulletin, 75(1), 6-13

Muhammad, G., Dunmeyer, A., Starks, F. D., \& Sealey-Ruiz, Y. (2020). Historical Voices for Contemporary Times: Learning from Black Women Educational Theorists to Redesign Teaching and Teacher Education. Theory Into Practice.

North, A. \& Cineas, F. (2020, July 13). Breonna Taylor was killed by police in March. The officers involved have not been arrested. Vox. https://www.vox.com/2020/5/13/21257457/breonna-taylor-louisville-shootingahmaud-arbery-justiceforbreonna

Nwigwe, T. (2020). Make it home [Song]. On The Pandemic Project. Tobe Nwigwe LLC.

Oscars. (2018, November 19). Ava DuVernay honors Cicely Tyson at the 2018 governors awards [Video]. Youtube.

https://www.youtube.com/results? search_query=ava+duvernay + speech+cisely+tys on

Pérez, M. S. (2017). Black feminist thought in early childhood studies:(Re) centering marginalized feminist perspectives. In Feminism (s) in Early Childhood (pp. 4962). Springer, Singapore.

Perkins, L. M. (1983). The impact of the "cult of true womanhood" on the education of Black women. Journal of Social Issues, 39(3), 17-28.

Richardson, L. \& St. Pierre, E. A. (2005). Writing: A method of inquiry. In N. K. Denzin \& Y. S. Lincoln (Eds.), The Sage handbook of qualitative research (3rd ed., pp. 959978). Sage.

Saldaña, J. (2015). The coding manual for qualitative researchers. Sage.

Smith, S. J. (2019). Septima Clark Yelled: A Revisionist History of Citizenship Schools. American Educational History Journal, 46(1/2), 95-110.

Solórzano, D. G., \& Yosso, T. J. (2002). Critical race methodology: Counter-storytelling as an analytical framework for education research. Qualitative inquiry, 8(1), 23-44. 
Thompson, B. (2017). Teaching with tenderness: Toward an embodied practice. University of Illinois Press.

Walker, Alice. 1983. In Search of Our Mothers' Gardens. New York: Harcourt, Brace Jovanovic.

FRANCHESKA D. STARKS , Ph.D., is a former public-school teacher with experience teaching students in grades K-12. She is currently an instructor at the University of West Georgia and her research focuses on the implications of social inequities on Black women and educators more broadly.

Email: fstarks1@gmail.com

S. MIA OBIWO, Ph.D., is an assistant professor of early childhood education, with emphasis in urban teaching and learning, at the University of Memphis. Her work examines the salience of urban teacher dispositions - a teacher's (un)conscious attitudes and beliefs that directly influence their instructional practices and relationships with young children, families, schools, and communities.

Email: smobiwo@memphis.edu

ADRIAN D. DUNMEYER, Ed.D., is a high school English teacher, writer, and researcher from Atlanta, GA. As a veteran high school teacher, Adrian uses her classroom to celebrate the identities and cultures of her students, while increasing literacy. As a researcher, her work centers Black women's work, and the intersectional experiences of Black girls and women in schools.

Email: adriandunmeyer@gmail.com

ARKERIA S. WRIGHT, Ed.D., is an elementary school teacher and professional child advocate. She began her work in education in 2005 as a literacy coach and student support advocate during her undergraduate studies at Spelman College. Dr. Wright earned her doctoral degree in Elementary Education specializing in Curriculum and Instruction in 2016. Email: Dr.ArkeriaWright@gmail.com

CHRISTAL WALKER, M.A.T., began her teaching career in 2015 working with elementary guided reading, close reading, and writing in Brooklyn, New York with Achievement First Charter Schools. She is currently a full-time teacher and pursuing her doctorate in the Department of Early Childhood and Elementary Education at Georgia State University with an anticipated graduation date May 2021. Email: Cwalker75@student.gsu.edu 